\title{
Baghdadi Method as Alternative System for Learning Qur'an at MT Nur Hikmah Mampang Depok City
}

\author{
Dewi Maharani ${ }^{1}$, Safitri Septiani ${ }^{2}$, Amanda Sahla Febriani ${ }^{3}$, Yeasy Agustina Sari ${ }^{4}$ \\ 1,2,3, Institut Ilmu Al-Qur'an (IIQ) Jakarta, Indonesia \\ ${ }^{4}$ Institut Agama Islam Negeri (IAIN) Metro Lampung, Indonesia \\ yeasy120708@gmail.com
}

\begin{tabular}{cl}
\hline & Abstract \\
\cline { 2 - 3 } & $\begin{array}{l}\text { This research is motivated by the fact that there are still many people who are } \\
\text { unable to read the Qur'an because they have not found t easy method of learning } \\
\text { in reading Qur'an.. To overcome this problem, efforts from various parties are } \\
\text { needed. For this reason, the teacher must ensure the right method and approach. }\end{array}$ \\
$\begin{array}{c}\text { ARTICLE INFO } \\
\text { Article history: } \\
\text { Received }\end{array}$ & $\begin{array}{l}\text { Because the right method will guarantee the achievement of a greater and more } \\
\text { comprehensive level of success. This research aims to improve the ability to read } \\
\text { the Qur'an, introduce harakat, and the preparation of hijaiyah letters based on } \\
\text { movember 11, } \\
\text { makharijul letters. The results of this research were obtained from observations, } \\
\text { Revised }\end{array}$ \\
$\begin{array}{c}\text { assessments that were tried twice, and interviews with children. Based on the } \\
\text { analysis of information on children's activities above, it can be concluded that the } \\
\text { dominant activity carried out is learning with the Baghdadi method, which is }\end{array}$ \\
Accepted
\end{tabular} $\begin{aligned} & \text { 30\%, on the contrary, based on interviews, the Baghdadi method is very } \\
& \text { appropriate and interesting to use. So it can be concluded that this method is very } \\
& \text { interesting and supports the learning process of children. The results of the last } \\
& \text { test showed an increase in understanding of reading the Qur'an so that it reached } \\
& \text { the predetermined success indicators. }\end{aligned}$

Published by

Keywords: Baghdadi Method, Learning Qur'an, System of Learning Qur'an

Lembaga Penelitian dan Pengabdian Kepada Masyarakat

Institut Agama Islam Negeri Metro

Website http://e-journal.metrouniv.ac.id/index.php/tapis/index

This is an open access article under the CC BY SA license

https://creativecommons.org/licenses/by-sa/4.0/

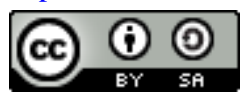

\section{INTRODUCTION}

Along with the times, we must pay more attention to children's education, especially in learning the Qur'an. Al-Qur'an learning needs to be carried out from an early age continuously by Muslims so that they can develop themselves systematically and live life according to the rules of the Qur'an as a guide for their lives, so that they can become human beings with good morals.

The Al-Qur'an learning method basically has the same goal, which is to teach children about recognizing letters and the sound signs of these letters (Syarif Hidayat, et al., 2018). But on the other hand, not all methods can be applied to each individual child, moreover these goals are often not supported by a strong commitment so that a teacher in teaching the Qur'an to children is sometimes unaware of minor or severe errors in pronunciation makharijul letters as well as in the rules of tajwid.

The above phenomenon is in line with the opinion of the scholars of the fast method of learning the Qur'an, the result finding said that until now there are still many 
Indonesian Muslims who have not been able to read the Qur'an, because they have not found a fast and easy method to learn to read the Qur'an. -Qur'an so lazy to learn (Husein \& Slama, 2017; Syamsudin, 2017). Based on the reality in the field, the results of the report published on Republika.co.id, the Chancellor of the Higher Education of Al-Qur'an Science (PTIQ) Jakarta (Prof Nazaruddin Umar, 2018) assesses that the number of people who are illiterate in the Qur'an is still high in Indonesia, especially in remote areas. Data from the Central Statistics Agency (BPS) in 2013 stated that there were about $54 \%$ of the total Muslim population in Indonesia who could not read the Qur'an. Meanwhile, based on research from the Jakarta Institute of Qur'anic Sciences (IIQ), around 65\% of Indonesians are still illiterate in the Qur'an. One of the reasons why there are still many people who are illiterate in the Qur'an is the lack of Koran teachers, especially in the regions (Nisa, 2018). ("Republika.co.id" https://www.google.com/amp/s/m.republika.co.id/amp/ p2a36z335, accessed on August 4, 2020).

To overcome this, efforts are needed from various parties. One of them that is very important is the efforts of the Al-Qur'an teacher himself on how to teach the Qur'an effectively so that children can easily understand what the teacher is teaching. For this reason, it is imperative for teachers to determine the right method and approach. Because, with the right method will guarantee the achievement of a higher and even rate of success. Methods of learning to read and write the Qur'an have also developed in Indonesia for a long time (Ma'mun Syarif, and Asmaran, 2018). Each method was developed following the times and based on its characteristics. Although each learning method in it has advantages and disadvantages, for a teacher, accuracy in choosing a method that suits the situation and condition of the students is very important. For example when teaching reading the Qur'an. The teacher of the Qur'an should choose a method that allows him to give as many examples as possible to students.

At this time many methods in learning to read the Qur'an are used, including the Baghdadi method. The Baghdadi method is an old method of studying the Qur'an. As the name implies, this method was born in Baghdad, Iraq, during the reign of the Abbasid dynasty. Compared to other Qur'anic learning methods, Baghdadi has several advantages, including laying the foundation for understanding the Qur'an. Learning this method requires each student to memorize the names of the letters before assembling them with vowels.

The Baghdadi method is taught in two volumes. In the first volume, students are introduced to the hijaiyah letters, various vowels to tanwin. At the end of the first volume, students will learn the form of letters coupled with other letters in a sentence. In the second volume, students began to teach reading tajwid, explained about the length of the reading, reverberation, and various things in the science of recitation (Republika.co.id" www.google.com/amp/s/m.republika.co.id/amp/nfxy1r44, accessed on 31 July 2020).

Baghdadi's method is not a rigid method, it can be changed according to the needs of the times. As published by Jam'iyyatul Qurra' wal Huffazh, the baghdadi 
method is formatted even more attractively, both in terms of appearance and distribution, so that it is no different from the fast method of reading the Qur'an that exists today (Abdul Rosyid. et al, 2018).

From the explanation above, the writer offers the Baghdadi method as an alternative method that is appropriate and easy to apply to children. This method is provided for people who want to learn the Qur'an in the right way and can be used by all ages, especially children. The efforts in this study are expected to help the community, especially the children of the Nur Hikmah taklim assembly through the implementation of the Al-Qur'an learning method with the Baghdadi method in order to improve the ability to read the Qur'an.

Based on the arguments above, in general the author will contain 4 ideas to be studied in depth, including; 1) Baghdadi Method An Alternative Al-Qur'an Learning System, 2) Characteristics of the Baghdadi Method, 3) Implementation of the Baghdadi Method at the Majlis Taklim Nur Hikmah Mampang, Depok City.

\section{RESEARCH METHODS}

This study used a descriptive analytical method with a qualitative approach. It is hoped that this method will provide in-depth information on the issues previously mentioned. In addition, this study will also analyze some of the things studied, so that it will produce a clear picture of Learning the Qur'an with the Baghdadi Method.

This research was carried out at the Nur Hikmah taklim assembly which is located in the Mampang sub-district, Depok city, the parties who were used as research subjects were children aged 11-14 years. The type of data required is primary data, namely the results of interviews and observations about the Learning of the Qur'an with the Baghdadi Method in Children. Secondary data, namely data obtained in the form of written records about various activities or events in the past, both in the form of archives including books, journals and literature relevant to the object of research, as well as documents related to research on during the learning process of the Koran. This secondary data excavation was carried out before going into the field and some of it was collected during the research process. The research process is carried out in stages. The initial step begins with data collection (data collection). Then the results of the collection are reduced. This reduction activity includes summarizing, selecting the main points and focusing on the important things from a number of field data that have been obtained and looking for patterns.

This study uses data collection techniques through observation or observation, interviews, and document analysis (historical method). This research was carried out through observation stages to find a general description of the topic under study, exploration as an effort to classify data, and the implementation of research carried out through interviews, observations, documentation studies and literature studies. 


\section{DISCUSSION AND FINDINGS}

\section{A. Alternative Learning System of Baghdadi Al-Qur'an Method}

The method of al-baghdadiyah is a method of learning the Qur'an by way of spelled per letter (Muhammedi, 2018) The Baghdadi method is an old method which is better known by the Indonesian people as "Turutan" this method is the oldest method to appear and the first method that is very developed in Indonesia.

This method was re-published by the Central Leadership of Jamiyatul Qurra' wal Huffazh (PPJQHNU) by adjusting the teaching system while maintaining existing examples (NU Online, "https://www.nu.or.id/post/read/60947/pd-pontrenadakan-training-baca-qurrsquoan-method-baghdadi-atau-ldquoturutanrdquo", accessed on 30 July 2020).

Among the Nahdliyin, since a long time ago, before the emergence of new methods of learning the Qur'an, children had learned to read the Qur'an through the baghdadi method. Baghdadi's method, although very simple, has contributed a lot to the community to be able to read the Qur'an. Jam'iyyatul Qurra' wal Huffazh has the desire that the Baghdadi method, which has a historical past, can still be used in the present times.

The series of Al-Qur'an Learning in the Baghdadi method consists of:

1. Basic books (Qaidah Baghdadiyah), advanced (Juz 'Amma), practice (Mushaf Baghdadi), companion books (guidelines for writing the Qur'an and a collection of songs and prayers).

\section{Figure 1: Method Learning Guide Panduan Baghdadi}



\section{Basic Book 1 A Basic Book 1 B Advanced Book}

2. The emphasis of learning lies on awareness of the pronunciation of letters according to makhraj and their nature.

3. The next lesson lies in the harmony of reading: for example, mad dua harakat, the tempo of hum nun and mim tasydid, and others.

4. At the basic level, students are only led to imitate the teacher's reading and the teacher listens and improves student reading.

5. More detailed recitation terms are found in juz 'Amma accompanied by an introduction to the difference in punctuation between the standard manuscripts and the Medina manuscripts.

6. Discussions about waqaf-ibtida' and musykilatul sentences are found in Baghdadi's manuscripts accompanied by the meaning of thepegon and wordsi'rabul Qur'an.

\section{B. Characteristics of the BaghdadiBaghdadi}

Method Themethod $A l$ - has a characteristic, namely that it immediately introduces the letters, and when the letters are punctuated (fathah, kasroh, dhommah), the syllables are spelled using the original term.techniques Al-Baghdadi designed to enable every society to learnAl-Quran.The book model uses a system of structure, analysis and sissis or SAS, solid and concise and creative through the discovery of teaching aids or ABM which is usually called a tap. This tap tool is believed to attract the interest of students or students who want to learn the Qur'an using the Al-Baghdadi method in a more fun way and stimulate the creativity of students. This tap tool is a teaching tool that aims to give a better impression in peroses learning and teaching of the Qur'an.Mechanical beats were found capable of disciplining readers ofAl-Quranto master reading with more fluent and orderly and disciplined reader capable of giving birth in the readings. Didactically, the materials are ordered from concrete to abstract, from easy to difficult, from general to detailed or more specific. Broadly speaking, the qaidah baghdadiyah requires 17 steps. 30 hijaiyah letters are always displayed in full in each step. It is as if these numbers have become the central theme with various variations. The variation of each step creates an aesthetic sense for students or students (pleasant to hear) because it sounds rhythmic rhymes, beautiful to look at because of the writing of the same letters, this method is taught classically or privately.

\section{Implementation of the Baghdadi Method at Majlis Taklim Nur Hikmah Depok City}

In achieving a learning, it is necessary to have steps that need to be carried out in order to achieve an interesting method and support the child's learning process in improving understanding of reading the Qur'an so as to achieve the indicators of success that have been set. determined. Therefore, the following 
stages in the research implementation of learning using the Baghdadi method in children were carried out effectively on July 13, 2020 to July 28, 2020.

\section{Making Media to Support Al-Qur'an Learning}

The first stage in this study was the researcher made media to support learning The Qur'an is in the form of a whallchart for children before the implementation of teaching. This learning media is made using easily available materials including cardboard, styrofoam, and colored markers. The selection of designs using colors and good proportion settings makes it more fun for children to learn the Qur'an, so that the lessons delivered can be more focused on the material and make children more interactive in learning.

\section{The application of the Baghdadi Method to Children}

The second stage is the application of learning the Qur'an with the Baghdadi method in the basic book (Qaidah baghdadiyah) volume 1A makes children very interested because in this Baghdadi method children are taught to recognize harakat and hijaiyah letter arrangement by using the tone "Sika and Jiharka", so that it is easier for children to learn it. In this learning, the teacher uses the classical-individual technique, namely the child together recites the names of the harakat using a sika tone, reads repeatedly until he can and finally the teacher appoints the child to ask the child to practice it. Qaidah Baghdadi is equipped with a collection of tones or rhythms of the Qur'an which are presented in volume 1A of this book, making it easier for children to learn it. Each page of this book has a clearly structured discussion section of the material.

After being taught classically, the individual children read Al-Qur'an one by one in turn according to what was taught in the classical technique. However, in this section, the teacher gives examples of what the students want to read, then the students follow and are guided by the teacher.

The steps taken by the teacher in using the Baghdadi method in recognizing vowels and the arrangement of hijaiyah letters based on where the letters are issued are as follows:

\section{Recognizing harakat}

a. Students are introduced to the name of the harakat starting with $b a-b i-b u$, both in form and sound as well as proper pronunciation, then sing this harakat material with a Sikah tone. The Sikah tone applied in learning the Baghdadi method can be seen on YouTube with the following link: https://youtu.be/CYwwtUBrxsg

b. The letter hijaiyah $b a$ is repeated and gives a syakal (line) fathah, kasrah, dhammah.

c. Each hijaiyah letter is repeated and developed with the tanwin syakal (fathah tanwin, kasrah tanwin and dhammah tanwin).

d. The harakat material is repeated from the beginning until it can be 


\section{2. letter composition}

a. arranged HijaiyahStudents are introduced to the hijaiyah letter arrangement based on the place where the letter that sings jiharka comes out through theillustrated media whalchart, the first is the halqiyyah letter (the letter that comes out of the throat) by distinguishing between the lower, middle, and upper throat Above, after students know exactly where the letters come out, students are guided to practice them.

b. The second arrangement of letters is the oral letters (letters that move the tongue), students are introduced to where the letters come out through theillustrated media whalchart by distinguishing between the base, middle, and tip of the tongue after students know the exact place where the letters come out, students are guided to practice it.

c. The third arrangement of letters is theletters syafawiyah (letters that move the lips), students are introduced to where the letters come out through a whalchart illustrated media, after students know the exact place where the letters come out, students are guided to practice it.

d. The fourth letter arrangement is jaufiyah letters (mad letters), students are introduced to where the letters come out through theillustrated media whalchart, after students know the exact place where the letters come out, students are guided to practice it.

e. The fifth letter arrangement is the letter khoisyumiyah (read mim and nun ghunnah), students are introduced to where the letters come out through a whalchart illustrated media, after students know exactly where the letters come out, students are guided to practice it.

Based on the research that has been done, the following are the results of the data on the achievement of the implementation of activities in learning obtained from observations, evaluations and interviews with Nur Hikmah's taklim children. Children's activities will be analyzed by calculating the percentage of students during the research process.

a. Children's activity "Listening or paying attention to the teacher's explanation" obtained a percentage of $19 \%$.

b. Children's activities "question and answer between children and teachers" get a percentage of $25 \%$.

c. Children's activities "learn using the baghdadi method $30 \%$.

d. The child's activity "Listening and paying attention to other friends when reciting the hijaiyah letters" obtained a percentage of $15 \%$.

e. Children's activities "irrelevant behavior" obtained a percentage of 5.7\%.

Based on the analysis of the children's activity data above, it can be concluded that the dominant activity carried out is learning with the Baghdadi method, which is $30 \%$. 
The next stage is to conduct interviews with the children of the taklim assembly, totaling 13 informants, the interviews will be held on Sunday, August 2, 2020, from 15.00 WIB to 16.30 WIB.

Table 1. Table of Interview Results

\begin{tabular}{|c|c|c|}
\hline NO & QUESTION & ANSWER \\
\hline 1 & $\begin{array}{l}\text { What method does the teacher use } \\
\text { when teaching the Qur'an? }\end{array}$ & Baghdadi Method \\
\hline 2 & $\begin{array}{l}\text { In your opinion, what is the picture } \\
\text { of the implementation of the } \\
\text { Baghdadi method in the Nur } \\
\text { Hikmah taklim assembly? }\end{array}$ & $\begin{array}{l}\text { a. Initially introduced to the name } \\
\text { of the harakat using the } \\
\text { whallchart media, the form of } \\
\text { the vowel, how to pronounce it, } \\
\text { the material was repeated until } \\
\text { it was done. At the time of } \\
\text { learning this material there is } \\
\text { also a tone. } \\
\text { b. The hijaiyah letter arrangement } \\
\text { and the location of the letters } \\
\text { were introduced, after which the } \\
\text { teacher gave an example and } \\
\text { the students were guided in } \\
\text { reciting it. The material is } \\
\text { repeated until it is possible, and } \\
\text { the learning is also using tone }\end{array}$ \\
\hline 3 & $\begin{array}{l}\text { Is this activity suitable to be applied } \\
\text { to learning the Qur'an at the Nur } \\
\text { Hikmah taklim assembly? }\end{array}$ & Very Suitable \\
\hline 4 & $\begin{array}{l}\text { In your opinion, do you need to } \\
\text { continue the learning process of the } \\
\text { Qur'an using the baghdadi method } \\
\text { at the Nur Hikmah taklim assembly } \\
\text { or not? }\end{array}$ & Need to be continued \\
\hline \multirow[t]{2}{*}{5} & \multirow{2}{*}{$\begin{array}{l}\text { What should be evaluated from the } \\
\text { process of learning the Qur'an with } \\
\text { the Baghdadi method at the Nur } \\
\text { Hikmah taklim assembly? }\end{array}$} & $\begin{array}{l}\text { The collection of songs is added } \\
\text { You do }\end{array}$ \\
\hline & & n't need a lot of songs in learning \\
\hline 6 & $\begin{array}{l}\text { What are your difficulties in } \\
\text { learning the Qur'an using the }\end{array}$ & $\begin{array}{l}\text { It's difficult to recite some oral } \\
\text { letters, halqiyah, because you still }\end{array}$ \\
\hline
\end{tabular}




\begin{tabular}{|c|c|c|}
\hline & \multirow{2}{*}{$\begin{array}{l}\text { Baghdadi method at the Nur } \\
\text { Hikmah taklim assembly? }\end{array}$} & \multirow{2}{*}{$\begin{array}{l}\text { like to beat and change the makhraj } \\
\text { It's not difficult, alhamdulillah }\end{array}$} \\
\hline & & \\
\hline 7 & $\begin{array}{l}\text { Do you like learning the Qur'an } \\
\text { using the baghdadi method? }\end{array}$ & Yes, I like \\
\hline 8 & $\begin{array}{l}\text { What factors cause you to like } \\
\text { learning the Qur'an using the } \\
\text { Baghdadi method? }\end{array}$ & $\begin{array}{l}\text { Because the lessons are not boring, } \\
\text { the teachers are not boring and the } \\
\text { learning is fun. }\end{array}$ \\
\hline 9 & $\begin{array}{l}\text { What are the learning materials for } \\
\text { the Al-Qur'an using the Baghdadi } \\
\text { method that are taught at the Nur } \\
\text { Hikmah assembly? }\end{array}$ & $\begin{array}{l}\text { The material is familiar with the } \\
\text { harakat and the arrangement of } \\
\text { hijaiyah letters based on } \\
\text { makhorijul letters, such as the } \\
\text { letters halqiyah, verbaliyah, } \\
\text { syafawiyah, jaufiyah and } \\
\text { khoisyumiyah }\end{array}$ \\
\hline 10 & $\begin{array}{l}\text { What do you think about learning } \\
\text { the Qur'an with the Baghdadi } \\
\text { method? }\end{array}$ & Good, interesting, and fun \\
\hline \multirow[t]{2}{*}{11} & \multirow[t]{2}{*}{$\begin{array}{l}\text { What are the advantages and } \\
\text { disadvantages of the Baghdadi } \\
\text { method? }\end{array}$} & $\begin{array}{l}\text { The advantage is that the } \\
\text { discussion of the material is very } \\
\text { detailed, so you know more about } \\
\text { the locations of the hijaiyah letters. } \\
\text { The }\end{array}$ \\
\hline & & $\begin{array}{l}\text { disadvantage is that you cannot } \\
\text { move the learning material if you } \\
\text { have not read it correctly. }\end{array}$ \\
\hline
\end{tabular}

Based on the results of the interview above, it can be concluded that learning the Qur'an with the Baghdadi method is suitable and interesting to apply. in learning the Qur'an, so it is no different from the fast method of reading the Qur'an that exists today. 
Figure 1. Photo of the Implementation of the Interview
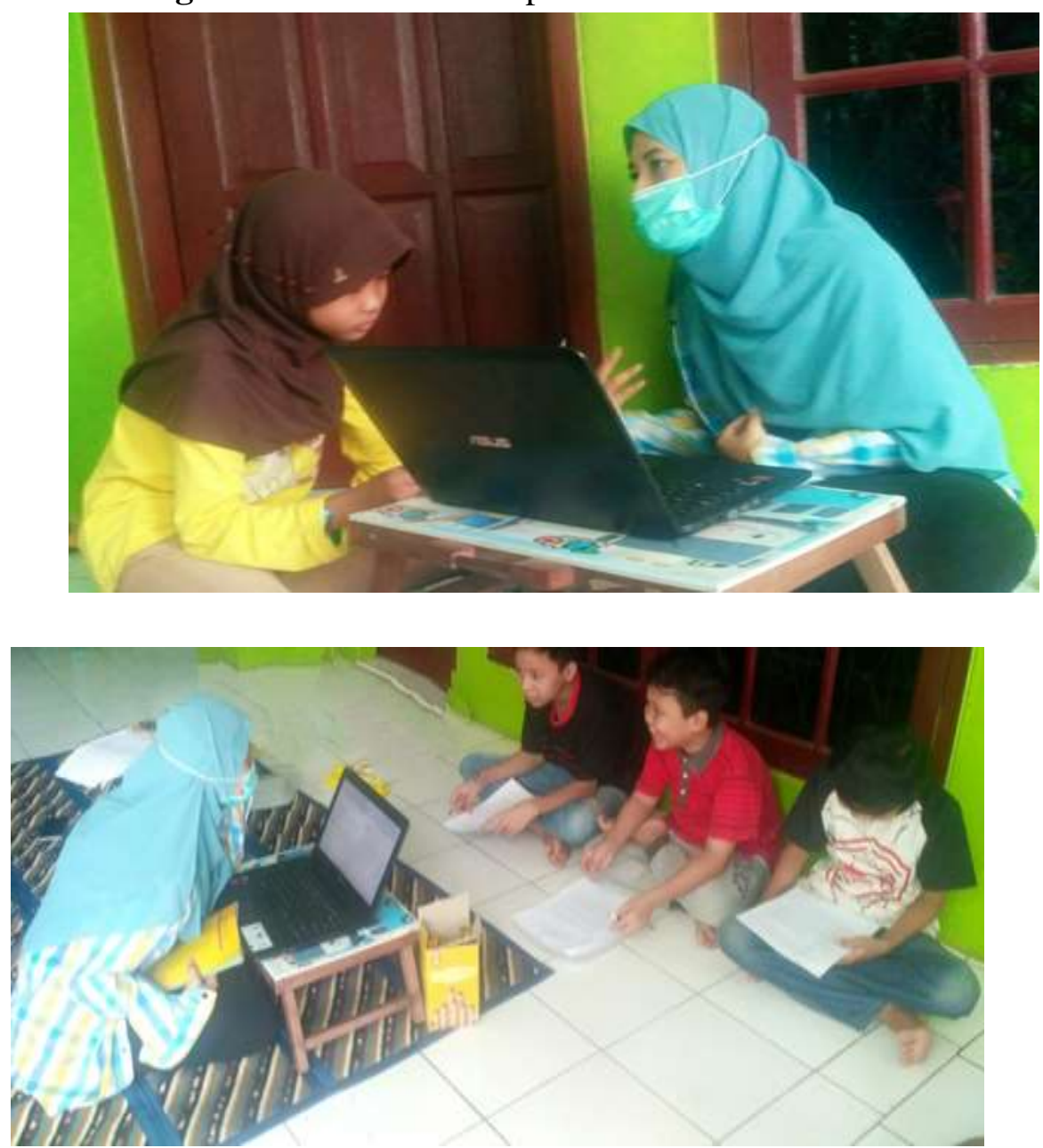

Reflection was carried out to evaluate the learning that had been done. Based on the results of the oral test through the practice of reading the Qur'an at the 1 st meeting which was attended by 13 participants or all children. Of the 13 children who took the test, only 7 children read the Qur'an fluently with a note that they understood the harakat and the pronunciation of some hijaiyah letters according to their makhraj, while the other 6 children got the category quite fluent and also not fluent with notes that they were still confused about the form. and the sound of harakat fathah and kasrah, and confused about the location of the hijaiyah letters in the same arrangement of letters.

Based on the results of observations of student activities in the learning process of meetings 1-2, which was observed by 1 observer. There are several factors that affect children's test results at the 3rd meeting, namely there are some students who are less active in learning and often carry out irrelevant behavior such as not listening to the teacher's explanation, chatting to themselves, joking and others. Because the indicators of success have not been achieved, improvements will be made at the next meeting. Reflection at the 3rd 
meeting aims to evaluate the learning process designed at the 4-5th meeting. Based on the results of the oral and written tests at the 3rd meeting, 13 children participated. As a result, there were 10 children who already knew the harakat, both from the form and the way it was pronounced correctly, and understood the hijaiyah letter arrangement quite well. While the other 3 children are quite familiar with the harakat, both in the form and the way of pronunciation and are still very inaccurate in pronouncing the hijaiyah letters.

\section{Advantages and Disadvantages of the Baghdadi Method}

In carrying out an activity, of course, there are advantages and disadvantages, here are the advantages in learning the Baghdadi method: 1) Children will be easy to learn because before being given the material, students have memorized the hijaiyah letters. fluent children will quickly move on to the next material, 2) The material is arranged sequentially, 3) All hijaiyah letters are almost always displayed in each step as a whole as a central theme. 4) The sound and arrangement of the letters are neatly arranged, 5) The spelling skills that are developed are the main attraction to lay the foundation for understanding the Qur'an. 6) This method is equipped with a guide book for writing the Qur'an as well as a collection of songs and prayers.

While the shortcomings (weaknesses) in the Baghdadi method can be described as follows: 1) It takes a long time because you have to memorize the hijaiyah letters according to the location of the letters, 2) the appearance of the same letters and makhroj sometimes makes students confused if they don't know the nature of the letters. each hijaiyah letter.

Baghdadi method is a structured method, meaning that it is a method that is arranged sequentially and is a reprocessing or better known as the Alif, ba ${ }^{e e}$, ta method. This method is the oldest method that appeared around the 1980s and is used by the Indonesian people, even this method is also the first method developed in Indonesia. This book of Al-Baghdadi's method only consists of one volume and is commonly known as the small Qur'an or sequence. Unfortunately, no one has been able to reveal the history of its invention, development and learning methods to date. Based on the statement above, it can be concluded that the Al-Baghdadi method derived from Bahdad is a method in which the way to read it is spelled first and children who use this method must memorize the Hijaiyah letters. Learning using the Al-Baghdadi method is the teacher who is more active than the students because children have to follow their ustadz-ustadzah. This method takes a long time because the child must memorize the Hijaiyah letters. 


\section{CONCLUSION}

This study is in the form of implementing the learning of the Qur'an for children using the Baghdadi method. Based on the results of this study, three achievements can be made, first is the use of whallchart media, which is a media that in its use is able to please children in learning, especially learning the Qur'an, so that the lessons delivered can be more focused on the material and make children more interactive in learning. Second, the application of Al-Qur'an learning with the Baghdadi method in the basic book (Qaidah baghdadiyah) volume 1A makes children very interested because in this Baghdadi method children are taught to recognize the harakat and the arrangement of hijaiyah letters by using the tone "sika and jiharka", so that easier for children to learn. Third, learning achievement is seen from observation, evaluation and interviews. From the results of observations obtained data regarding children's activities during this learning process that children do a lot of activities in learning the Qur'an with the baghdadi method. Based on the results of interviews, it was found that learning the Qur'an with the Baghdadi method is suitable and interesting to be applied in learning the Qur'an. Meanwhile, based on the results of oral and written tests at the 1st and 3rd meetings, it was found that the children experienced an increase in reading comprehension of the Qur'an.

\section{ACKNOWLEDGEMENT}

The article was supported by Lembaga Pengabdian Masyarakat (LP2M) Institut Ilmu Al-Qur'an (IIQ) Jakarta and Institut Agama Islam Negeri (IAIN) Metro Lampung.

\section{AUTHOR CONTRIBUTION STATEMENT}

The authors had participated in the research and approved the final version of the manuscript.

\section{REFERENCES}

Adibudin, Al Halim A and Nurul, Azizah Wida, "Efforts to Improve the Ability to Read Al-Qur'an Through Recognition of Hijaiyah Letters Using the Qo'idah Baghdadiyah Method Ma'a Juz. 'Amma (Record) In Class 1A Ma'arif NU 01 Tritih kulon for the 2015/2016year"academic, in the journal Tawadhu, Vol. 2 No. 1, 2018.

Ahmad, Saebani Ahmad and Akhdiyat Hendra, (ed.), Islamic Education, Bandung: CV Pustaka Setia, 2012.

Al-Qur'an and Translation, Almahira: Jakarta, 2017.

Dony, Purnama, Muhamad, at All, "Implementation of Al-Qur'an Learning Methods for Santri Age Tamyiz at Kuttab Al-Fatih Bantarjati Bogor”, in PAI prose: Proceedings of Al Hidayah Islamic Religious Education, 2019.

Fathoni, Ahmad, (ed.), Tahsin Practice Instructions Tartil Al-Qur'an Maisura Method, CV Duta Grafika: Bogor, 2016. 
Nurdin, Ali, (ed.), Quoted from the author's foreword "Al-Qur'an Solutions for Life", South Tangerang: Nurummubin Foundation, 2018.

Hidayat, Syarif, et al., see the Implementation of the At-Tahsin Method in improving the Ability to Read the Qur'an at the Hunafa Anak Saleh and Shalehah Al-Qur'an Education Park (TPA) in Jagakarsa District, South Jakarta City, in the Proceedings of Al-Hidayah : Islamic Religious Education, 2018.

Husein, F., \& Slama, M. (2018). Online piety and its discontent: revisiting Islamic anxieties on Indonesian social media. Indonesia and the Malay World, 46(134), 80-93.

Muhammedi, "Al Baghdadiyah Method (Effective Learning Method in Instilling Religious Attitudes) ius Students and Improving Learning Outcomes of Islamic Religious Education)" in Al-Fatih: Journal of Islamic and Educational Education, Vol. I. No. January 1 - June,. 2018.

Nisa, E. F. (2018). Social media and the birth of an Islamic social movement: ODOJ (One Day One Juz) in contemporary Indonesia. Indonesia and the Malay world, 46(134), 24-43.

NU Online, "https://www.nu.or.id/post/read/60947/pd-pontren-adakan-training-bacaqurrsquoan-method-baghdadi-or-ldquoturutanrdquo", accessed on 30 July 2020 .

Permana, Hinggil and Syafrida, Rina,"KnowYour Skills Through letters Hijaiyah Ottoman Methods and MethodsBaghdadi",in the journal: Child Education, Vol. 5 No. 2, 2019.

Rosyid, Abdul, MA, at.all, Quoted from PPJHQNU's remarks in the book "The Right Way to Learn the Qur'an: The Baghdadi Method", Jakarta: Center for Training and Development of the Baghdadi Method /P3MB, 2018.

Sadiah, at.all, "Implementation of Learning Models in Eradicating Al-Qur'an Illiteracy at the Nurul Hikmah Taklim Council, Situ Uncal Village, Purwasari Village, Dramaga District, Bogor Regency", in PAI Prose: Proceedings of Al Hidayah Islamic Religious Education, 2018.

Syamsuddin, S. (2017). Ma'na cum Maghza Approach to The Qur'an: Interpretation of Q. 5: 51.”. Jurnal Advances in Social Science, Education and Humanities Research, 137, 131-136.

Syarif, Ma' Mun and Asmaran, "Application of Classical Methods in Al-Qur'an Learning at Madrasah Ibtidaiyah Nurul Islam Banyu Hirang Gambut”, in Darris: Journal of Madrasah Ibtidaiyah Education Vol. 1 No. April 1, 2018.

"Republica.co.id" https://www.google.com/amp/s/m.republika.co.id/amp/p2a36z335, accessed on August 4, 2020

"Republica.co.id" www .google.com/amp/s/m.republika.co.id/amp/nfxy1r44, accessed on July 31, 2020.

"Republika.co.id), www.google.com/amp/s/m,republika. co.id/amp/pgfc9e366, accessed on August 4, 2020 


\section{Copyright Holder :}

(C) Dewi Maharani, et al., (2021).

First Publication Right :

(C) Tapis : Jurnal Penelitian Ilmiah

This article is under:

CC BY SA 